\title{
First evidence of the conversion of paracetamol to AM404 in human cerebrospinal fluid
}

This article was published in the following Dove Press journal: Journal of Pain Research

Chhaya V Sharma,' Jamie H Long, ${ }^{2}$ Seema Shah,' Junia Rahman,' David Perrett, ${ }^{3}$ Samir S Ayoub, ${ }^{4}$ Vivek Mehta'

'Pain \& Anaesthesia Research Centre, St Bartholomew's and The Royal London Hospitals, Barts Health NHS Trust, London, UK; ${ }^{2}$ Barts \& The London School of Medicine, Queen Mary University of London, London, UK; ${ }^{3}$ BioAnalytical Science, Barts \& The London School of Medicine, Queen Mary University of London, London, UK; ${ }^{4}$ School of Health, Sport and Bioscience, Medicines Research Group, University of East London, London, UK

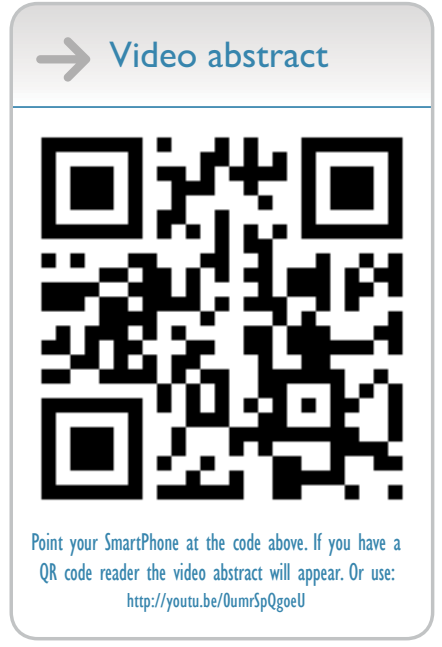

Correspondence: Chhaya V Sharma Department of Anaesthesia, 4th Floor, North Tower, Royal London Hospital, Whitechapel, EI IBB, London, UK Email Chhaya.Sharma@bartshealth.nhs.uk

\begin{abstract}
Paracetamol is arguably the most commonly used analgesic and antipyretic drug worldwide, however its mechanism of action is still not fully established. It has been shown to exert effects through multiple pathways, some actions suggested to be mediated via $\mathrm{N}$-arachidonoylphenolamine (AM404). AM404, formed through conjugation of paracetamol-derived p-aminophenol with arachidonic acid in the brain, is an activator of the capsaicin receptor, TRPV1, and inhibits the reuptake of the endocannabinoid, anandamide, into postsynaptic neurons, as well as inhibiting synthesis of $\mathrm{PGE}_{2}$ by COX-2. However, the presence of AM404 in the central nervous system following administration of paracetamol has not yet been demonstrated in humans. Cerebrospinal fluid (CSF) and blood were collected from 26 adult male patients between 10 and 211 minutes following intravenous administration of $1 \mathrm{~g}$ of paracetamol. Paracetamol was measured by high-performance liquid chromatography with UV detection. AM404 was measured by liquid chromatography-tandem mass spectrometry. AM404 was detected in 17 of the 26 evaluable CSF samples at 5-40 $\mathrm{nmol} \cdot \mathrm{L}^{-1}$. Paracetamol was measurable in CSF within 10 minutes, with a maximum measured concentration of $60 \mu \mathrm{mol} \cdot \mathrm{L}^{-1}$ at 206 minutes. This study is the first to report on the presence of AM404 in human CSF following paracetamol administration. This may represent an important finding in our understanding of paracetamol's mechanism of action, although measured concentrations were far below the previously documented IC50 for this metabolite.
\end{abstract}

Keywords: acetaminophen, paracetamol, paracetamol: mechanism of action, AM404, $\mathrm{N}$-arachidonoylphenolamine, pharmacology - theories of analgesic action

\section{Introduction}

Despite its discovery over a century ago and ubiquitous clinical use, the mechanism of action of paracetamol remains undetermined, although involvement of multiple central pathways has been demonstrated. These include effects on prostaglandin production, ${ }^{1,2}$ on serotonergic pathways, ${ }^{3,4}$ and more recently, there has been increasing evidence for the roles of the endocannabinoid system and TRPV1 receptor in paracetamol's antinociceptive (though not its hypothermic) effects. ${ }^{5-8}$

Arachidonoyl ethanolamine (AEA, anandamide) is an endogenous cannabinoid present in the human nervous system, with demonstrated antinociceptive actions. Its actions are terminated by a two-step inactivation process beginning with its reuptake from the synaptic cleft into the postsynaptic neuron by a recently characterized FAAH-like anandamide transporter (FLAT). ${ }^{9}$ Inside the neuron, AEA is hydrolyzed by the enzyme FAAH. Paracetamol has been suggested to exert its analgesic actions by interfering with the reuptake of AEA by using FAAH to form a novel metabolite 
$\mathrm{N}$-arachidonoylphenolamine (AM404) through conjugation in brain tissue of paracetamol-derived para-aminophenol with arachidonic acid. ${ }^{10}$ The consequence of this is increased AEA within the synaptic cleft, producing increased cannabinoid receptor $\left(\mathrm{CB}_{1}\right)$ activation. ${ }^{10,11} \mathrm{AM} 404$ is also an activator of TRPV1, otherwise known as the capsaicin receptor. ${ }^{7,10}$

Although the potential central antinociceptive role of AM404 has been investigated in animal models, its role in humans is not clear. AM404 has been found only as a metabolite of paracetamol and is not an endogenous component of human or animal nervous systems. ${ }^{7,12}$ However, its presence in cerebrospinal fluid (CSF) following paracetamol administration in humans has not been reported. The purpose of this pilot study was to investigate whether AM404 is present in human CSF following a single intravenous dose of paracetamol.

\section{Methods}

\section{Study design and patient randomization}

Following approval by the East London Research Ethics Committee (ref: 2010-019488-12), EudraCT registration (ref: 2010-019488-12), and receipt of written informed consent from all participants, 30 American Society of Anesthesiology classification of perioperative risk of anesthesia I-III adult male and female patients, aged between 18 and 80 years, were recruited to the study. These patients were scheduled to undergo elective urological surgery under spinal anesthesia. Exclusion criteria were any contraindication to spinal anesthesia, known hypersensitivity to paracetamol or severe hepatocellular insufficiency, patients taking paracetamol in the preceding 12 hours, or pregnancy or lactation in women. Patients were given a single intravenous dose of 1 g paracetamol (100 mL solution, Perfalgan; Bristol-Myers Squibb Pharmaceutical Limited, Middlesex, UK) as an infusion over 10 minutes, and were randomized for sample collection at 15,30 , or 120 minutes post-infusion, prior to their spinal anesthetic (administration to sampling interval). At the time of the lumbar puncture but before injection of intrathecal local anesthetic agents, CSF $(5 \mathrm{~mL})$ and blood (10 mL) samples were collected.

Randomization was achieved using sealed envelopes containing the study group allocation (for sampling at 15, 30, or 120 minutes post-paracetamol administration). The sealed envelope was selected by a member of the research team not involved in data collection or analysis. ${ }^{13}$ As outcomes of the study were measured values of paracetamol and its metabolite, AM404, rather than subjective patient experience, clinical bias was not a concern and masking was not carried out.

\section{Sample collection and storage}

CSF and blood sample were collected into EDTA tubes, stored on ice, centrifuged at $1,400 \times g$ at $4^{\circ} \mathrm{C}$ for 15 minutes, and then frozen at $-20^{\circ} \mathrm{C}$ until analysis.

\section{Materials}

Paracetamol reference samples were from Sigma-Aldrich Co. (St Louis, MO, USA); AM404 and palmitoylethanolamided4 (PEA-d4) were from Cayman Chemicals (Ann Arbor, MI, USA); ammonium acetate, potassium phosphate, and EDTA were from VWR (Lutterworth, UK). Analytical grade methanol, acetonitrile, $\mathrm{H}_{2} \mathrm{O}$, and formic acid were from Fisher Scientific UK Ltd (Loughborough, UK).

\section{Measurement of paracetamol in CSF and plasma}

High-performance liquid chromatography (HPLC) analysis was performed on a Jasco system. CSF $(100 \mu \mathrm{L})$ was diluted with $100 \mu \mathrm{L} 50 \mathrm{mM}$ ammonium acetate, $\mathrm{pH} 5.5$, containing $183 \mathrm{mmol} . \mathrm{mL}^{-1} 3$-aminophenol (internal standard). One hundred microliters of plasma was precipitated with $300 \mu \mathrm{L}$ acetonitrile containing $183 \mathrm{mmol} . \mathrm{mL}^{-1} 3$-aminophenol. Extracted plasma was centrifuged at $13,000 \times g$ for $10 \mathrm{~min}-$ utes and $100 \mu \mathrm{L}$ supernatant was diluted with $100 \mu \mathrm{L} 50 \mathrm{mM}$ potassium phosphate, $\mathrm{pH} 6.5$. Extracts were injected $(20 \mu \mathrm{L}$ for CSF, $10 \mu \mathrm{L}$ for plasma) and separated on a Thermo Scientific C18 column $(100 \times 4.6 \mathrm{~mm}, 5 \mu \mathrm{m})$. For CSF, elution was carried out with $50 \mathrm{mM}$ ammonium acetate ( $\mathrm{pH}$ 5.5) containing $1 \mathrm{mM}$ EDTA and 5\% methanol. For plasma, $50 \mathrm{mM}$ potassium phosphate ( $\mathrm{pH}$ 6.5) containing $1 \mathrm{mM}$ EDTA and $5 \%$ methanol was used. The column was eluted at $1 \mathrm{~mL} \cdot \mathrm{min}^{-1}$ using a Jasco PU-980 pump. Detection was at $242 \mathrm{~nm}$ using a Jasco UV-975 detector. The retention time for paracetamol was 7.05 minutes and that of the internal standard was 3.5 minutes. The HPLC for paracetamol was calibrated to a six-point curve of $0-1.65 \mathrm{mmol} \cdot \mathrm{L}^{-1}$. The matrix was PBS for CSF and paracetamol-free human plasma for plasma samples. The limit of detection for paracetamol in CSF and plasma were $54 \mathrm{nmol} \cdot \mathrm{L}^{-1}$ and $200 \mathrm{nmol} \cdot \mathrm{L}^{-1}$, respectively $(\mathrm{S} / \mathrm{N}=3)$. The limits of quantitation for paracetamol in CSF and plasma were $180 \mathrm{nmol} \cdot \mathrm{L}^{-1}$ and $600 \mathrm{nmol} \cdot \mathrm{L}^{-1}$, respectively $(\mathrm{S} / \mathrm{N}=10)$.

\section{Measurement of AM404 in CSF and plasma}

Liquid chromatography-tandem mass spectrometry (LCMS/MS) analysis was performed on a Thermo Scientific Accela system attached to a TSQ Vantage mass spectrometer. One hundred microliters of CSF was diluted with 
$100 \mu \mathrm{L} \mathrm{H}_{2} \mathrm{O}$. One hundred microliters of plasma was precipitated with $300 \mu \mathrm{L}$ acetonitrile containing $329 \mathrm{nmol} / \mathrm{L}$ internal standard PEA-d4. Extracts $(10 \mu \mathrm{L})$ were injected onto a Waters Acquity BEH phenyl column $(2.1 \times 50 \mathrm{~mm}$, $1.7 \mu \mathrm{m}$ ), maintained at $50^{\circ} \mathrm{C}$, and eluted at $0.5 \mathrm{~mL} \cdot \mathrm{min}^{-1}$. Initially, the eluent was $95 \%$ aqueous, $0.1 \%$ formic acid, $5 \%$ methanol, increasing linearly over 3 minutes to $95 \%$ methanol, $5 \%$ aqueous, $0.1 \%$ formic acid. This was held for 2 minutes and then returned to initial conditions to re-equilibrate. Positive electrospray ionization was used, with an ion spray voltage of 3,500 V and no declustering voltage applied. AM404 was detected by monitoring the $396.3 / 110.2 \mathrm{~m} / \mathrm{z}$ transition using a collision energy of $9 \mathrm{~V}$. The detection time for AM404 was 4.25 minutes. LC-MS/MS for AM404 was calibrated to an eight-point curve $0-300 \mu \mathrm{mol} \cdot \mathrm{L}^{-1}$. The limits of detection of AM404 in CSF and plasma were $0.1 \mathrm{nmol} \cdot \mathrm{L}^{-1}$ and $1.6 \mathrm{nmol} \cdot \mathrm{L}^{-1}$, respectively $(\mathrm{S} / \mathrm{N}=3)$. The limits of quantitation for AM404 in CSF and plasma were $0.5 \mathrm{nmol} \cdot \mathrm{L}^{-1}$ and $5 \mathrm{nmol} \cdot \mathrm{L}^{-1}$, respectively $(\mathrm{S} / \mathrm{N}=10)$. The $\mathrm{LC}-\mathrm{MS} / \mathrm{MS}$ parameters were set as follows: collision gas was argon, spray voltage was $3,500 \mathrm{~V}$, vaporizer temperature was $300^{\circ} \mathrm{C}$, sheath gas pressure was $60 \mathrm{psi}$, capillary temperature was $270^{\circ} \mathrm{C}$, collision cell pressure was $1.5 \mathrm{mTorr}$, and no declustering voltage was applied. Full details of the analytical methodologies are in Long. ${ }^{14}$

\section{Results}

\section{Patient recruitment}

Of the 30 patients recruited, only three were female. Additionally, two of the patients, one male and one female, were later found to have taken an additional dose of paracetamol in the previous 12 hours, violating exclusion criteria. Data from these four patients were therefore excluded from analysis, such that results from 26 male patients were analyzed in total (Table 1).

As expected, given the unpredictable nature of the operating theater lists, it was not possible to collect samples precisely at the intended time points. CSF samples were collected over a range of 10-206 minutes and blood over

Table I Characteristics and sampling times for 26 male patients receiving I g intravenous paracetamol at various time intervals prior to samples taken for determination of paracetamol and AM404 concentrations in blood and CSF

\begin{tabular}{|c|c|c|c|c|c|c|c|}
\hline $\begin{array}{l}\text { Randomization } \\
\text { group (minutes) }\end{array}$ & $\begin{array}{l}\text { Paracetamol- } \\
\text { CSF time } \\
\text { (minutes) }\end{array}$ & $\begin{array}{l}\text { Paracetamol- } \\
\text { blood time } \\
\text { (minutes) }\end{array}$ & $\begin{array}{l}\text { CSF/blood } \\
\text { interval } \\
\text { (minutes) }\end{array}$ & $\begin{array}{l}\text { Age } \\
\text { (years) }\end{array}$ & $\begin{array}{l}\text { Height } \\
\text { (m) }\end{array}$ & $\begin{array}{l}\text { Weight } \\
\text { (kg) }\end{array}$ & $\begin{array}{l}\text { BMI } \\
\left(\mathrm{kg} \cdot \mathrm{m}^{-2}\right)\end{array}$ \\
\hline 15 & 10 & 15 & 5 & 77.8 & 1.68 & 57 & 20.2 \\
\hline 15 & 15 & 25 & 10 & 78.9 & 1.65 & 68 & 22.7 \\
\hline 15 & 15 & 21 & 6 & 72.7 & 1.73 & 68 & 25.0 \\
\hline 15 & 15 & 17 & 2 & 51.9 & 1.70 & 95 & 32.9 \\
\hline 15 & 15 & 18 & 3 & 34.9 & 1.75 & 125 & 40.8 \\
\hline 15 & 16 & 25 & 9 & 75.1 & 1.81 & 92 & 28.1 \\
\hline 15 & 20 & 27 & 7 & 77.9 & 1.67 & 85 & 30.5 \\
\hline 15 & 20 & 27 & 7 & 56.8 & 1.63 & 86 & 32.4 \\
\hline 30 & 25 & 29 & 4 & 78.8 & 1.69 & 52 & 18.1 \\
\hline 15 & 26 & 28 & 2 & 56.8 & 1.78 & 74 & 23.4 \\
\hline 30 & 33 & 38 & 5 & 56.0 & I.7I & 61 & 20.9 \\
\hline 30 & 35 & 35 & 0 & 64.7 & 1.59 & 78 & 30.9 \\
\hline 30 & 35 & 40 & 5 & 45.1 & 1.76 & 83 & 26.8 \\
\hline 30 & 38 & 42 & 4 & 77.8 & I.82 & 76 & 22.9 \\
\hline 30 & 40 & 46 & 6 & 78.6 & 1.80 & 109 & 33.6 \\
\hline 120 & 54 & 57 & 2 & 65.1 & 1.74 & 93 & 30.7 \\
\hline 120 & 56 & 62 & 6 & 75.5 & 1.90 & 120 & 33.2 \\
\hline 30 & 68 & 74 & 6 & 68.7 & 1.82 & 93 & 28.1 \\
\hline 120 & 81 & 85 & 4 & 57.7 & 1.76 & 88 & 28.4 \\
\hline 120 & 82 & 87 & 5 & 54.6 & 1.53 & 65 & 27.8 \\
\hline 30 & 82 & 85 & 3 & 64.0 & 1.72 & 81 & 27.4 \\
\hline 30 & 86 & 73 & 7 & 75.5 & 1.60 & 57 & 22.3 \\
\hline 120 & 117 & 121 & 4 & 76.6 & 1.70 & 86 & 29.8 \\
\hline 120 & 128 & 134 & 6 & 67.7 & 1.70 & 77 & 26.6 \\
\hline 120 & 147 & 150 & 3 & 65.8 & 1.81 & 104 & 31.9 \\
\hline \multirow[t]{2}{*}{120} & 206 & 211 & 5 & 56.5 & 1.75 & 92 & 30 \\
\hline & & & Mean $( \pm S D)$ & $65(12)$ & $1.72(0.1)$ & $83(19)$ & $27.9(5)$ \\
\hline
\end{tabular}

Abbreviations: AM404, N-arachidonoylphenolamine; BMI, body mass index; CSF, cerebrospinal fluid. 
15-211 minutes. The mean CSF-blood collection interval was 4.9 minutes, ranging 0-10 minutes (Table 1).

\section{CSF and plasma sample analyses}

Following intravenous administration, paracetamol and AM404 were measured in CSF and plasma (Table 2). Paracetamol was detectable in CSF at 10 minutes at $5 \mu \mathrm{mol} \cdot \mathrm{L}^{-1}$, and at a maximal measured concentration of $99 \mu \mathrm{mol} \cdot \mathrm{L}^{-1}$. In plasma, the paracetamol concentration ranged from 92 to $506 \mu \mathrm{mol} \cdot \mathrm{L}^{-1}$ (Table 2, Figure 1).

AM404 was detected in 17 of the 26 evaluable CSF samples from 10 minutes post-administration; 14 of these were above the level of reliable quantitation of $5 \mathrm{nmol} \cdot \mathrm{L}^{-1}$, ranging mostly from 5.1 to $57.4 \mathrm{nmol} \cdot \mathrm{L}^{-1}$ with one anomalous measurement of $166.8 \mathrm{nmol} \cdot \mathrm{L}^{-1}$. Measured AM404 concentrations in CSF did not correlate with time of collection (Figure 2). AM404 was detectable in only eight of the 26 plasma samples, with three being above the limit of quantitation $\left(>5 \mathrm{nmol} \cdot \mathrm{L}^{-1}\right)$, ranging from 6.1 to $65.4 \mathrm{nmol} \cdot \mathrm{L}^{-1}$.

\section{Discussion}

Evidence for a pharmacological function of paracetamolderived AM404 in rodents has been previously documented; ${ }^{6,7,10}$ however, there is no evidence of a similar metabolic pathway in human tissues. The current study is the first to report on the presence of AM404 in human CSF and plasma samples following intravenous administration of $1 \mathrm{~g}$ paracetamol.

AM404, a putatively active metabolite of paracetamol and apparent intermediary in several analgesic pathways in animal models, ${ }^{7,10,15}$ was measured in CSF in 14 of 26 patients at concentrations of 5.1-57.4 nmol. $\mathrm{L}^{-1}$ with an outlier at $166.8 \mathrm{nmol} \cdot \mathrm{L}^{-1}$; it was also detectable in a further three human CSF samples below the level of reliable quantitation $\left(<5 \mathrm{nmol} \cdot \mathrm{L}^{-1}\right)$. AM404 was not detected in plasma in the majority of subjects in this study, consistent with findings of Högestätt et al, ${ }^{10}$ who reported on the absence of AM404 in rat plasma. In the present study, AM404 above $5 \mathrm{nmol} \cdot \mathrm{L}^{-1}$ was, however, found in the plasma of three of the 26 patients (range: 6.1-65.4 $\mathrm{nmol} \cdot \mathrm{L}^{-1}$ ). This finding warrants further

Table 2 Paracetamol and AM404 concentrations in plasma and CSF at various time intervals following intravenous administration of I g of paracetamol in 26 male patients

\begin{tabular}{|c|c|c|c|c|c|}
\hline \multicolumn{3}{|l|}{ Plasma } & \multicolumn{3}{|l|}{ CSF } \\
\hline $\begin{array}{l}\text { Sample time } \\
\text { (minutes) }\end{array}$ & $\begin{array}{l}\text { Paracetamol } \\
\left(\mu \mathrm{mol} \cdot \mathrm{L}^{-1}\right)\end{array}$ & $\begin{array}{l}\text { AM404 } \\
\left(\mathrm{nmol} \cdot \mathrm{L}^{-1}\right)\end{array}$ & $\begin{array}{l}\text { Sample time } \\
\text { (minutes) }\end{array}$ & $\begin{array}{l}\text { Paracetamol } \\
\left(\mu \mathrm{mol} \cdot \mathrm{L}^{-1}\right)\end{array}$ & $\begin{array}{l}\text { AM404 } \\
\left(\mathrm{nmol} \cdot \mathrm{L}^{-1}\right)\end{array}$ \\
\hline 15 & 441 & 0.0 & 10 & 5 & 5.4 \\
\hline 17 & 286 & 0.0 & 15 & 10 & 166.8 \\
\hline 18 & 256 & 0.0 & 15 & 5 & 5.1 \\
\hline 21 & 417 & 6.1 & 15 & 11 & 0.0 \\
\hline 25 & 402 & 0.0 & 15 & 14 & 0.0 \\
\hline 25 & 271 & 65.4 & 16 & 12 & 22.6 \\
\hline 27 & 351 & 0.0 & 20 & 78 & 10.6 \\
\hline 27 & 289 & 1.7 & 20 & 42 & 0.0 \\
\hline 28 & 319 & 0.0 & 25 & 24 & 0.0 \\
\hline 29 & 351 & 0.0 & 26 & 39 & 2.6 \\
\hline 35 & 506 & 0.0 & 33 & 32 & 18.2 \\
\hline 38 & 341 & 0.0 & 35 & 37 & 8.0 \\
\hline 40 & 213 & 0.0 & 35 & 35 & 0.0 \\
\hline 42 & 265 & 2.0 & 38 & 25 & 33.9 \\
\hline 46 & 216 & 23.6 & 40 & 19 & 32.9 \\
\hline 57 & 188 & 0.0 & 54 & 27 & 0.0 \\
\hline 62 & 167 & 0.5 & 56 & 27 & 16.2 \\
\hline 73 & 410 & 4.0 & 68 & 55 & 0.0 \\
\hline 74 & 168 & 0.0 & 81 & 47 & 0.7 \\
\hline 85 & 206 & 3.3 & 82 & 99 & 57.4 \\
\hline 85 & 191 & 0.0 & 82 & 61 & 0.5 \\
\hline 87 & 247 & 0.0 & 86 & 92 & 8.1 \\
\hline 121 & 118 & 0.0 & 117 & 61 & 5.2 \\
\hline 134 & 150 & 0.0 & 128 & 62 & 0.0 \\
\hline 150 & 92 & 0.0 & 147 & 44 & 0.0 \\
\hline 211 & 130 & 0.0 & 206 & 71 & 10.4 \\
\hline
\end{tabular}

Abbreviations: AM404, $\mathrm{N}$-arachidonoylphenolamine; CSF, cerebrospinal fluid. 


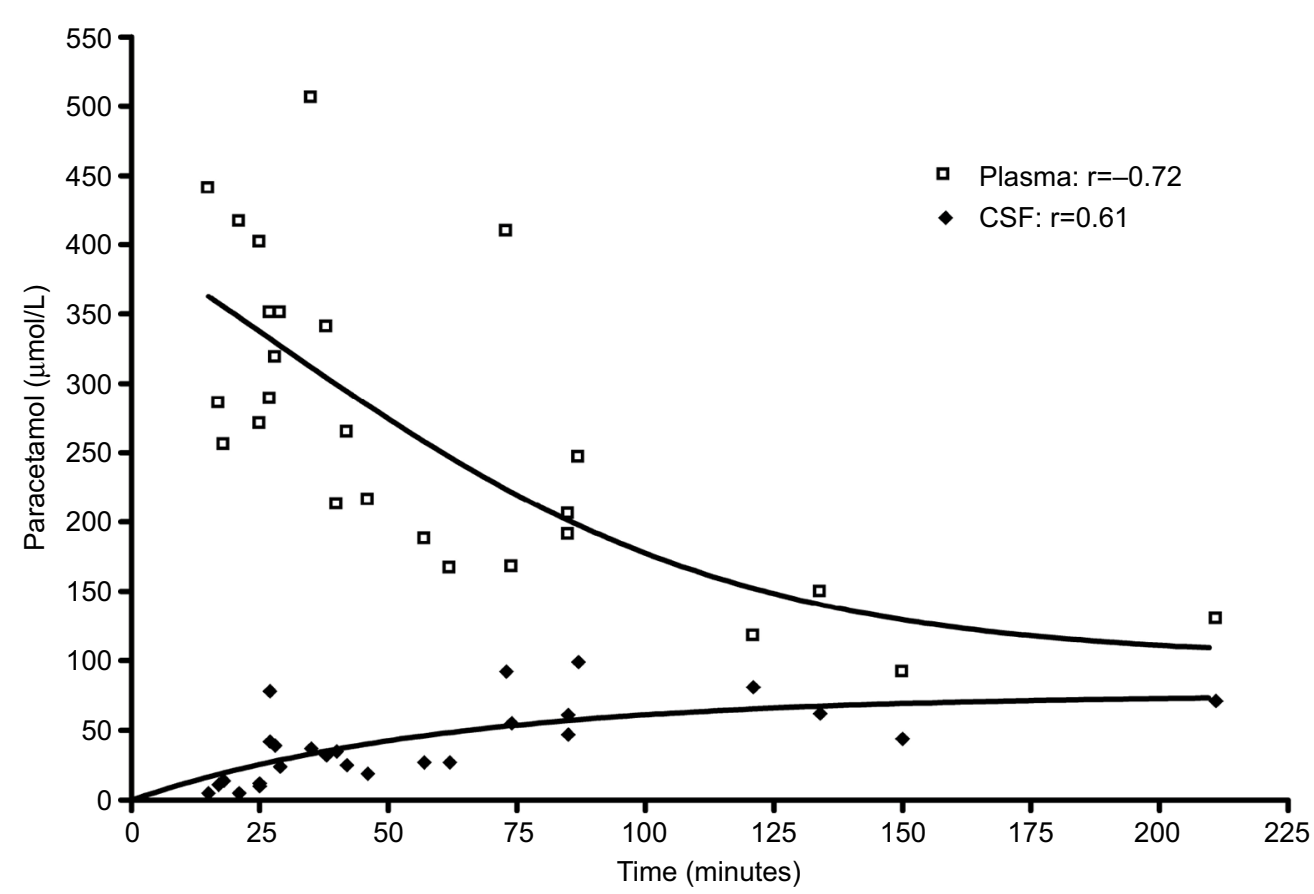

Figure I The concentration of paracetamol in plasma and CSF over time from 26 male patients given a single intravenous dose of I $g$ paracetamol.

Notes: The concentration of paracetamol was measured using HPLC with a detection time of 7.05 minutes. The concentration of paracetamol in plasma steadily declined over time with concentrations ranging from 506 to $92 \mu \mathrm{mol} \cdot \mathrm{L}^{-1}$. In CSF, paracetamol was detected as early as 10 minutes with concentrations ranging from 5 to $99 \mu \mathrm{mol} \cdot \mathrm{L}^{-1}$. Abbreviations: CSF, cerebrospinal fluid; HPLC, high-performance liquid chromatography.

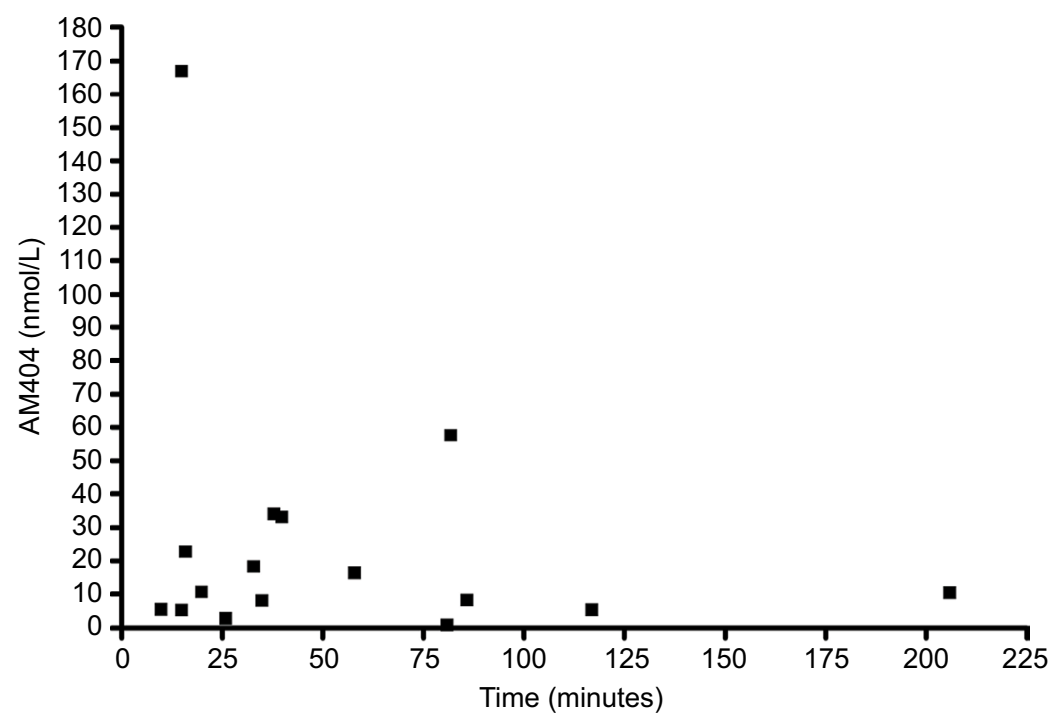

Figure 2 Using LC-MS/MS techniques, AM404 was detected in the CSF of 17 out of the 26 male patients treated with a single intravenous dose of I $g$ of paracetamol. Notes: In 14 patients, the AM404 concentration was above the detection limit for quantitation $\left(5 \mathrm{nmol} \cdot \mathrm{L}^{-1}\right)$ with concentrations ranging from $5 . \mathrm{I}$ to $57.4 \mathrm{nmol} \cdot \mathrm{L}^{-1}$ over 10 to 206 minutes. One patient anomalously showed a very high concentration of AM404 (I66.8 nmol. $\mathrm{L}^{-1}$ after 15 minutes of paracetamol administration). Abbreviations: AM404, N-arachidonoylphenolamine; CSF, cerebrospinal fluid; LC-MS/MS, liquid chromatography-tandem mass spectrometry.

investigation as there would appear to be a mechanism through which AM404 leaks out of the brain and into blood, but is only functional in some individuals.

Although this study reports the presence of AM404 in human CSF, the exact pathway and clinical relevance in humans remain unclear, as the evidence to date on AM404 comes largely from animal studies. AM404 has been demonstrated in in vitro studies to inhibit reuptake of anandamide, ${ }^{9,10,15,16}$ TRPV1 receptor activity, ${ }^{10,11}$ and $\mathrm{PGE}_{2}$ production via COX-1 and COX-2, ${ }^{10}$ in the high nanomolar to low micromolar concentration range. Ex vivo animal studies have detected levels of AM404 in whole brain tissue equating to the low nanomolar range following systemic administration of standard analgesic doses of paracetamol in rats 
(300 mg. $\left.\mathrm{kg}^{-1}\right) \cdot{ }^{10}$ Using the hot plate test of acute nociception, it was found that AM404 at a dose of $10 \mathrm{mg} \cdot \mathrm{kg}^{-1}$ potentiated the analgesic action of anandamide. ${ }^{16}$ Additionally, it was shown that $1-10 \mathrm{mg} \cdot \mathrm{kg}^{-1}$ attenuated the formalin-induced and chronic constriction injury models of acute and chronic pain, respectively, in a $\mathrm{CB}_{1}$ receptor-dependent manner. ${ }^{17}$

In the present study, nanomolar concentrations of AM404 were measured in human CSF samples taken from low level lumbar puncture. As FAAH is mostly expressed in discrete areas of brain tissue, ${ }^{10,16}$ it is hypothesized that AM404 would be formed predominantly in the brain following administration of paracetamol, from where it diffuses into CSF. Ex vivo rat studies support this, with the majority of AM404 (following paracetamol administration) being found in brain tissue, to a lesser extent in the spinal cord (15-fold less), and negligible amounts in plasma. ${ }^{10}$ It is likely, therefore, that human CSF concentrations of AM404 (surrogate measures of brain concentration) significantly underestimate the concentration in areas of the brain rich in FAAH. Levels measured in this study may therefore correspond to much greater amounts formed in human brain following paracetamol administration.

Several investigations aimed at elucidating the pharmacological mechanism of action of paracetamol have reported on paracetamol-derived AM404 playing a key role in mediating the analgesic action of paracetamol in rodents. Mallet et al demonstrated that inhibition of brain FAAH activity, thereby preventing the conversion of paracetamol into AM404, suppressed the analgesic action of paracetamol in animal models of thermal, mechanical, and chemical pain. ${ }^{6}$ The authors also propose that AM404 mediates these analgesic actions through activation of $\mathrm{CB}_{1}$ receptor and 5-HT descending inhibitory pathway. These findings have been extended to also propose involvement of TRPV1 as an analgesic target for paracetamol-derived metabolites. ${ }^{18}$ A recent study by Muramatsu et al reported on the metabolism of paracetamol to AM404 in rats at doses of paracetamol similar to therapeutic doses in humans. ${ }^{19}$ However, the authors report on a conversion rate of paracetamol to AM404 of only $0.0013 \%$ with claims of analgesic significance, which has not been demonstrated. Using pharmacological and genetic approaches to abolish the expression or function of FAAH to prevent the synthesis of AM404, it was demonstrated that the hypothermic action of paracetamol was similar to control mice and that the observed paracetamol-induced hypothermia was not dependent on cannabinoids or TRPV $1 .{ }^{8}$
Historical as well as somewhat recent investigations on the mechanism of action of paracetamol have focused on direct or indirect inhibition of the activity of the COX enzymes as the target for the analgesic action of paracetamol., ${ }^{1,220,21}$ These in vitro and in vivo experiments consistently demonstrated reduction of brain and spinal cord prostaglandin synthesis, which is likely to be an action either directly of paracetamol or through AM404.

This study does not report on the pharmacokinetic modeling of paracetamol, which has been previously welldocumented. ${ }^{22,23}$ A study by Kumpulainen et al on the CSF pharmacokinetics of paracetamol in children, using serial sampling following a $15 \mathrm{mg} \cdot \mathrm{kg}^{-1}$ intravenous dose, ${ }^{22}$ showed paracetamol to be rapidly detectable, within 5 minutes, and reaching a maximum concentration equivalent to $119 \mu \mathrm{mol} \cdot \mathrm{L}^{-1}$ at 57 minutes. Another study, by Singla et al, on plasma and CSF pharmacokinetics following intravenous paracetamol in healthy adults reports a CSF $\mathrm{C}_{\max }$ of $39 \mu \mathrm{mol} \cdot \mathrm{L}^{-1}$ at 2 hours. ${ }^{23}$ These figures corroborate our findings that paracetamol rapidly enters the CSF following intravenous administration, detectable as early as 10 minutes in the low $\mu \mathrm{mol} \cdot \mathrm{L}^{-1}$ range (Figure 1 ).

Although this study reports the presence of AM404 in human CSF, the extent of its clinical relevance remains unclear. The IC50 of AM404 for AEA uptake or EC50 for TRPV1 activation have not been measured in human CSF, though in rat neural tissue, the IC50 for AEA uptake has been found to be $\sim 5 \mu \mathrm{mol} \cdot \mathrm{L}^{-1} \cdot{ }^{9,10}$ In the present study, concentrations ranging 5.1-57.4 $\mathrm{nmol} \cdot \mathrm{L}^{-1}$ with an outlier at $166.8 \mathrm{nmol} \cdot \mathrm{L}^{-1}$ were measured. However, as mentioned previously, it is possible that these low concentrations of AM404 in CSF correspond to much higher levels in FAAH-rich areas of the brain.

Further to the identification of a potential central antinociceptive role of AM404 in animal models, its presence in CSF in humans following paracetamol administration is a significant finding, reported here for the first time. Whilst this represents a potentially important step in furthering our understanding of paracetamol's mechanism(s) of action, given the extremely low levels of AM404 detected in the CSF, its role in the clinical actions of paracetamol requires further investigation.

\section{Acknowledgment}

This paper was presented as an abstract and poster at the 31 st Annual Scientific Meeting of the American Pain Society, Honolulu, Hawaii, May 16-19, 2012.

\section{Disclosure}

The authors report no conflicts of interest in this work. 


\section{References}

1. Flower RJ, Vane JR. Inhibition of prostaglandin synthetase in brain explains the antipyretic activity of paracetamol (4-acetamidophenol). Nature. 1972;240(5381):410-411.

2. Muth-Selbach US, Tegeder I, Brune K, Geisslinger G. Acetaminophen inhibits spinal prostaglandin E2 release after peripheral noxious stimulation. Anesthesiology. 1999;91(1):231-239.

3. Pickering G, Loriot MA, Libert F, Eschalier A, Beaune P, Dubray C. Analgesic effect of acetaminophen in humans: first evidence of a central serotonergic mechanism. Clin Pharmacol Ther. 2006;79(4):371-378.

4. Pickering G, Estève V, Loriot MA, Eschalier A, Dubray C. Acetaminophen reinforces descending inhibitory pain pathways. Clin Pharmacol Ther. 2008;84(1):47-51.

5. Ottani A, Leone S, Sandrini M, Ferrari A, Bertolini A. The analgesic activity of paracetamol is prevented by the blockade of cannabinoid $\mathrm{CB}_{1}$ receptors. Eur J Pharmacol. 2006;531(1-3):280-281.

6. Mallet C, Daulhac L, Bonnefont J, et al. Endocannabinoid and serotonergic systems are needed for acetaminophen-induced analgesia. Pain. 2008;139(1):190-200.

7. Mallet C, Barrière DA, Ermund A, Jönsson BA, Eschalier A, Zygmunt PM, Högestätt ED. TRPV ${ }_{1}$ in brain is involved in acetaminopheninduced antinociception. PLoS One. 2010;5(9). pii:e12748.

8. Ayoub SS, Pryce G, Seed MP, Bolton C, Flower RJ, Baker D. Paracetamol-induced hypothermia is independent of cannabinoids and transient receptor potential vanilloid-1 and is not mediated by AM404. Drug Metab Dispos. 2011;39(9):1689-1695.

9. Fu J, Bottegoni G, Sasso O, et al. A catalytically silent FAAH-1 variant drives anandamide transport in neurons. Nat Neurosci. 2011;15(1): 64-69.

10. Högestätt ED, Jönsson BA, Ermund A, et al. Conversion of acetaminophen to the bioactive $\mathrm{N}$-acylphenolamine AM404 via fatty acid amide hydrolase-dependent arachidonic acid conjugation in the nervous system. J Biol Chem. 2005;280(36):31405-31412.

11. Zygmunt PM, Chuang H, Movahed P, Julius D, Högestätt ED. The anandamide transport inhibitor AM404 activates vanilloid receptors. Eur J Pharmacol. 2000;396(1):39-42.
12. Costa B, Siniscalco D, Trovato A, et al. AM404, an inhibitor of anandamide uptake, prevents pain behaviour and modulates cytokine and apoptotic pathways in a rat model of neuropathic pain. Br J Pharmacol. 2006;148(7):1022-1032.

13. Doig GS, Simpson F. Randomization and allocation concealment: a practical guide for researchers. J Crit Care. 2005;20(2):187-193.

14. Long JH, Control of analgesic and anti-inflammatory pathways by fatty acid amide hydrolase [thesis]. Queen Mary University of London; 2012.

15. Giuffrida A, Beltramo M, Piomelli D. Mechanisms of endocannabinoid inactivation: biochemistry and pharmacology. J Pharmacol Exp Ther. 2001;298(1):7-14.

16. Beltramo M, Stella N, Calignano A, Lin SY, Makriyannis A, Piomelli D. Functional role of high-affinity anandamide transport, as revealed by selective inhibition. Science. 1997;277(5329):1094-1097.

17. La Rana G, Russo R, Campolongo P, et al. Modulation of neuropathic and inflammatory pain by the endocannabinoid transport inhibitor AM404 [ $N$-(4-Hydroxyphenyl)-eicosa-5,8,11,14-tetraenamide]. J Pharmacol Exp Ther. 2006;317(3):1365-1371.

18. Barrière DA, Mallet C, Blomgren A, et al. Fatty acid amide hydrolasedependent generation of antinociceptive drug metabolites acting on TRPV $_{1}$ in the brain. PLoS One. 2013;8(8):e70690.

19. Muramatsu S, Shiraishi S, Miyano K, et al. Metabolism of AM404 from acetaminophen at human therapeutic dosages in the rat brain. Anesth Pain Med. 2016;6(1):e32873.

20. Malmberg AB, Yaksh TL. Capsaicin-evoked prostaglandin $\mathrm{E}_{2}$ release in spinal cord slices: relative effect of cyclooxygenase inhibitors. Eur J Pharmacol. 1994:271(2-3):293-299.

21. Ayoub SS, Colville-Nash PR, Willoughby DA, Botting RM. The involvement of a cyclooxygenase 1 gene-derived protein in the antinociceptive action of paracetamol in mice. Eur J Pharmacol. 2006;538(1-3):57-65.

22. Kumpulainen E, Kokki H, Halonen T, Heikkinen M, Savolainen J, Laisalmi M. Paracetamol (acetaminophen) penetrates readily into the cerebrospinal fluid of children after intravenous administration. Pediatrics. 2007;119(4):766-771.

23. Singla NK, Parulan C, Samson R, et al. Plasma and cerebrospinal fluid pharmacokinetic parameters after single-dose administration of intravenous, oral, or rectal acetaminophen. Pain Pract. 2012;12(7):523-532.
Journal of Pain Research

\section{Publish your work in this journal}

The Journal of Pain Research is an international, peer reviewed, open access, online journal that welcomes laboratory and clinical findings in the fields of pain research and the prevention and management of pain. Original research, reviews, symposium reports, hypothesis formation and commentaries are all considered for publication

\section{Dovepress}

The manuscript management system is completely online and includes a very quick and fair peer-review system, which is all easy to use. Visit http://www.dovepress.com/testimonials.php to read real quotes from published authors. 